\title{
OS NOMES DO PAI E A GENERALIZAÇÃO DA CASTRAÇÃO
}

Cristina Moreira Marcos e Eduardo Augusto de Souza Sales

Cristina Moreira Marcos

Pontifícia

Universidade

Católica de Minas

Gerais (PUC-

MG), Professora

do Programa de

Pós-Graduação em

Psicologia Clínica,

Belo Horizonte/

MG, Brasil.

Eduardo Augusto de

Souza Sales

Pontifícia

Universidade

Católica de Minas

Gerais (PUC-

MG), Mestre pelo

Programa de

Pós-Graduação em

Psicologia Clínica,

Belo Horizonte/

MG, Brasil.

RESUMO: Segundo Freud, os complexos de Édipo e de castração são fatores decisivos para se pensar a entrada do sujeito no "mundo" do desejo, da lei e da cultura. Lacan proporcionou uma nova leitura do Édipo freudiano ao pluralizar o Nome-do-Pai e trazer à discussão os modos singulares da presença da função paterna, pluralizada em diversos nomes. Lacan demonstra que a castração não é uma operação edípica, é, antes, uma operação de inscrição da linguagem. Nosso trabalho busca abordar a pluralização dos nomes do pai através do eixo da generalização da castração.

Palavras-chave: nomes do pai; castração; Édipo; função simbólica.

ABSTRACT: The names of the father and the generalization of castration. According to Freud, the Oedipus complex and the castration are crucial factors to think about the subject's entry into the "world" of desire, law and culture. Lacan provided a new reading of Freud's Oedipus, pluralizing the Name-of-the-Father and bringing to the discussion the singular ways of the presence of the paternal function, which is pluralized in various names. Lacan shows that castration is not an oedipal operation, but rather an inscription into language. In this paper, we address the pluralization of the Names-of-the Father, through the generalization of castration.

Keywords: father's names; castration; Oedipus; simbolic function. 


\section{INTRODUÇÃO}

Freud utilizou o mito para demonstrar o périplo da estruturação do sujeito. Em outros termos, o complexo de Édipo freudiano diz respeito a uma ficção construída pelo sujeito com o intuito de narrar os enigmas da sua origem. Lacan, ao efetivar a leitura do complexo de Édipo freudiano, estabelece uma importante noção teórica — o Nome-do-Pai. O autor (1957-1958/1999) analisa os efeitos simbólicos do Édipo e produz a desvinculação entre mito e psicanálise à medida que destaca o que há de estrutural no mito edípico.

Não obstante, a clínica evidencia a Lacan que o Édipo não responde plenamente ao enigma da estruturação do sujeito e do desejo. Haveria um resto da estruturação subjetiva que não é transcrito pelo simbólico. Com a elaboração da noção do objeto a, no seminário A angústia, Lacan (1962-1963/2005) teoriza a presença desse resto e, ao mesmo tempo, faz uma proposta inovadora no âmbito psicanalítico, indo além do Édipo freudiano.

Deste modo, a castração, operação privilegiada da primeira formulação sobre o pai, é questionada ao ser asseverado que a castração é uma prerrogativa da linguagem. Cabe ao pai pluralizado a incumbência de sustentar uma função suplementar, a saber, a ligação entre lei e desejo, e, por consequência, promover a fixação do desejo. É uma perversion que pode ser utilizada pelo sujeito para sustentar seu desejo; desejo este que tem como ponto inicial a castração.

\section{DE UM MITO FREUDIANO AO NOME-DO-PAI EM LACAN}

O complexo de Édipo compreende uma descoberta freudiana em relação ao modo com que se estrutura a subjetividade. Na tentativa de abarcar a realidade da estruturação subjetiva, Freud utilizará o mito como um dos suportes para a sua construção teórica, demonstrando a interseção entre a teoria e a clínica, que está presente na fundamentação do complexo de Édipo. Deste modo, os mitos que Freud encontrará em seu percurso, especialmente o Édipo e o mito do pai primevo, são avalizados pelos relatos que surgem dentro de sua prática clínica.

Freud (1900/1996) enxerga no mito elementos que correspondem ao drama humano diante do desejo, pois há uma equivalência entre essa narrativa e as cenas contadas pelos neuróticos durante as sessões clínicas. Em outros termos, essas cenas correspondem à intenção parricida e incestuosa presente nas fantasias neuróticas.

Freud inscreve, portanto, o complexo de Édipo como um périplo universal que cada humano vivencia na relação do sujeito com seu desejo. Deste modo, a criança deve abrir mão de seus desejos primordiais para alcançar a entrada no registro cultural e civilizatório. Logo, percebemos a presença da dualidade natureza/civilização na construção teórica de Freud, pois é por meio da resolu- 
ção do complexo de Édipo que há a passagem da instância da "natureza” para a "civilizatória”.

A clínica freudiana não revelou apenas o complexo de Édipo, isto é, o desejo parricida e incestuoso. Ela também revelou um momento de intensa produção de angústia que acentua a impossibilidade da realização dos desejos infantis: o complexo de castração. O complexo de castração demonstra que as intenções da criança em relação a seus genitores são refreadas na medida em que se impõe um entrave a eles. A formulação de Freud estabelece então que a mãe possibilita a libidinização da criança e o pai opera a castração e a interdição dos primeiros objetos de desejo.

A contribuição de Lacan para a teoria do Édipo começa a demonstrar seu peso a partir desse momento. Uma das intenções que a criança apresenta, nesse instante, é situar-se como um objeto privilegiado da mãe, tentativa fadada ao fracasso. Mas, ao mesmo tempo em que a criança deseja se manter nesse lugar, permanecer nele implica se submeter ao gozo materno e, nesse sentido, fica impossibilitado o acesso ao registro cultural-simbólico.

O Édipo, como representante da estruturação simbólica, evidencia a importância do simbólico contra os efeitos nocivos do gozo. A suposição de Lacan é que a estruturação do sujeito se dá a partir da submissão progressiva do Real em função do Simbólico. A criança deve simbolizar o Real de sua experiência pela via significante, inclusive a relação com seu objeto primordial, a mãe.

A posição da mãe como objeto primordial de satisfação advém da sua relação com a primeira experiência de satisfação pulsional, ou seja, sua posição se articula à função do Outro primordial. Através da amamentação, a criança vivencia sua primeira experiência de satisfação e, em seguida, busca repeti-la. Mas, como o objeto real não está presente, a criança tenta reeditá-la de modo alucinatório. Essa é a gênese do desejo humano, segundo Freud. Assim sendo, a mãe, por meio dessa experiência, proporciona à criança a erogenização do corpo, o que intensifica o desenvolvimento da dinâmica pulsional. Portanto, a mãe é fonte das mais primárias experiências de satisfação pulsional e se torna um objeto que comporta um gozo, e, por isso, deve ser proibido pelo pai.

O complexo de castração se articula ao pai de maneira determinante, sendo esta uma de suas funções por excelência. Ora, a criança não abre mão de sua posição de forma espontânea. Devido à resistência em sair desse lugar privilegiado junto à mãe, surgem inclinações parricidas que não advêm de outra parte senão do ódio que o filho nutre pelo pai, já que ele o impede de permanecer como objeto privilegiado. Deste modo, no mito freudiano, o pai é um entrave às intenções do filho sendo aquele que interdita seu desejo e priva a mãe, ao promulgar uma lei que torna o incesto impossível. 
O pai priva a mãe da tentativa de situar a criança como seu falo imaginário, conforme Lacan (1957-1958/1999) nos diz no seminário As formações do inconsciente. A mãe já é um ser que se submeteu ao simbólico, e, nesse sentido, a criança pode ser a sua tentativa de responder à falta simbólica.

Já a criança ainda está às voltas com sua estruturação simbólica. Sua condição inicial em relação à mãe é marcada por uma discrepância fundamental, uma vez em que ela depende fundamentalmente da mãe e está submetida aos seus caprichos e desejos. Depreende-se dessa afirmativa que a posição da criança é marcada pelo gozo, na medida em que está submetida ao gozo materno.

A ambiguidade da posição da criança em relação à mãe — permanecer como objeto privilegiado da mãe ou se livrar do gozo materno — tem na figura paterna seu desfecho. Se, a princípio, fica evidente que a criança odeia o pai por impedir seu desejo incestuoso, Freud (1924/1996) destaca também que há um amor da criança que se direciona a ele, e é esse amor que possibilitará a identificação que a criança estabelecerá com o pai, surgindo um Ideal ao qual ele deve se conformar.

Por todas essas razões, o pai é a figura central para o complexo de castração, o qual ganha seu contorno através das ameaças que anunciam uma punição frente à desobediência do mandamento e, ao mesmo tempo, propicia um modelo, um Ideal que lhe serve como um guia, uma referência para a sua trajetória.

A castração implica um limite; um ponto de vacilação do sujeito. Ao mesmo tempo, esta operação participa da estruturação do próprio sujeito. A princípio, a descoberta da castração se ancora na visão do outro sexo, fomentando a comparação imaginária dos corpos. Até então, as ameaças de castração proferidas pelo pai não faziam sentido, mas a percepção dos órgãos genitais do outro incide sobre o sujeito, marcando-o de modo indelével.

Diante desse fato, pode-se dizer que há uma distância entre a observação e as consequências que o sujeito elabora. Ao elaborar as consequências da perda do pênis, a criança irá significar todas as perdas anteriores, como o seio, as fezes etc., através do processo de retroação. Temos assim, em Freud, a diferença representada no nível do ter, precisamente do pênis real.

Freud (1923/1996) afirma que a castração opera no nível fálico, assertiva bastante difundida, que acaba incorrendo em inúmeros equívocos. Isto significa dizer que existe um instante da vida da criança em que o falo assume a primazia, uma vez que ela considera que todos os seres o possuem. No entanto, ao ser confrontada com as proibições impostas pelo pai, seguidas da constatação de que existem seres que não possuem falo, a criança será tomada de grande temor em relação à perda de seu pênis.

Para além da perda de um suposto objeto de satisfação plena da pulsão, a criança também assente à perda de uma posição privilegiada com a mãe. A partir desse ponto, ou seja, da castração, ela deverá encontrar seu caminho desejante, 
e isso mediante a lei paterna que, ao mesmo tempo em que interdita, também possibilita ao sujeito escolher outros objetos.

Portanto, temos no mito do Édipo a apresentação de uma versão bastante particular do pai. Isso não significa que em Freud não existam outras versões do pai (MARCOS, 2003). Entretanto, podemos dizer que esta versão ocupa um lugar privilegiado dentro de suas elaborações. Freud caracteriza o pai como um ser potente em sua incumbência de promulgar a castração e inserir o sujeito no registro cultural.

O Édipo, como fator universal o qual todos os seres falantes devem vivenciar, possibilita pensarmos de forma mais acurada o instante de origem do sujeito e a função do pai. Mas é em outro mito, o de Totem e tabu, que a ideia de um pai universal ganha consistência. $\mathrm{O}$ assassinato do pai primevo o eleva a uma condição de pai-morto, e, por isso, presente de forma veemente, não apenas para aqueles filhos que cometeram o parricídio, mas em todos os desenvolvimentos culturais subsequentes.

O pai-morto assinala o instante original da passagem no mundo da natureza para a cultura. Freud (1913/1996) demonstra que todo o desenvolvimento cultural parte desse ponto. Os filhos, ao abrirem mão do gozo, pois somente o pai poderia tê-lo, firmam uma aliança contra as inclinações da natureza, isto é, a posse de todas as fêmeas do bando. Passa a haver uma proibição contra o excesso, que somente pode ser reencontrado em um período circunscrito de tempo através do rito festivo do totemismo. Logo, de um lado, temos a lei e, de outro, um gozo que é reencontrado e recuperado durante esse período ritualístico.

Lacan (1957-1958/1999) destaca e analisa as versões freudianas do pai e empreende uma criteriosa análise dos mitos freudianos. Logo de início, podemos afirmar que esse fator universal é traduzido por Lacan e nomeado por ele com o termo Nome-do-Pai. Com efeito, o Nome-do-Pai é partícipe da primeira releitura que Lacan efetiva do Édipo freudiano.

O termo Nome-do-Pai tem sua origem na religião cristã, na qual a paternidade de Deus é claramente colocada pela figura do Cristo, embora a ideia sobre a paternidade de Deus não remonte apenas ao cristianismo. O próprio judaísmo, do qual o cristianismo descende, ratifica a ideia de um Deus pai. No entanto, sua paternidade é colocada apenas quando se trata do povo, e não de uma única pessoa. De qualquer maneira, Deus como um Pai-Universal é analisado por Lacan, que jamais o desarticulou da sua noção de Nome-do-Pai.

Desde os primeiros momentos do seu ensino, Lacan (1953/2008) afirma a necessidade de se analisar e criticar tudo aquilo que se entende sobre o complexo de Édipo. Para efetivar essa crítica, serão necessários alguns desdobramentos teóricos, que podem ser resumidos pela seguinte assertiva: Lacan desenvolverá 
sua noção sobre o Nome-do-Pai, que parte da categoria universal até desembocar no singular.

Podemos iniciar com a seguinte questão: Lacan (1957-1958/1999) entende que o mito do Édipo, e tudo o que ele comporta, expõe uma lógica primordial, a lógica da estruturação do sujeito e do desejo que está de acordo com as leis que regem o significante, ou seja, trata-se das leis da linguagem.

Por conseguinte, uma das principais alterações que Lacan efetua reside na desarticulação entre o pai real e a função paterna. Devemos lembrar que Lacan (1952) tripartiu o pai desde o seu seminário sobre O homem dos lobos e o retoma em seu seminário As formações do inconsciente (LACAN, 1957-1958/1999). O pai real é aquele que o sujeito tem a maior dificuldade em apreender devido à interposição das fantasias. O pai imaginário é o pai rival presente no nível da agressividade. Já o pai simbólico é aquele que está concernido ao significante. É o pai morto que retorna efetivando a castração do sujeito. Para o psicanalista, o pai morto está vinculado ao significante, ou seja, ao par ausência-presença.

Ademais, ele distingue três operações particulares que incidem sobre o sujeito, a saber, a privação, a frustração e a castração. A privação corresponde a uma falta real de um objeto que é simbólico, ou seja, a mulher possui uma falta real, que é a ausência de pênis, mas o objeto ao qual essa falta se refere é simbólico, o falo. Aquele que priva é então o pai imaginário - aquele que impõe a restrição à mãe de reintegrar a criança ao seu ventre.

A frustração diz respeito a um dano imaginário de um objeto que é real. Quem frustra a criança é a mãe, na medida em que a criança necessita dela. Nem sempre é possível à mãe satisfazê-la. Mas é a castração que privilegia a incidência simbólica no registro humano, incidindo sobre aquilo que é seu objeto privilegiado, os objetos imaginários. Essa fratura no imaginário implica não apenas na desarticulação dessa posição dual, mas também produz um impedimento do acesso ao gozo. O agente da castração é o pai real.

Lacan (1957-1958/1999) afirma que o pai é uma função que não se coaduna com um pai em sua concretude, isto é, a uma pessoa. Por isso, ele demonstra que existem sujeitos que não possuem o pai no eixo familiar, mas apresentam um Édipo perfeitamente normal, tanto no sentido de produzir os efeitos da neurose quanto também da normatização. O pai é uma função significante atrelada às leis da linguagem e, mais especificamente, à metáfora.

No seminário As formações do inconsciente, Lacan (1957-1958/1999) destaca o pai enquanto uma metáfora. A metáfora consiste na substituição significante, produzindo um efeito de significação. O Nome-do-Pai é o significante que substitui o significante do desejo materno, produzindo uma significação ao final de seu processo. Em suma, a função da metáfora paterna é substituir o significante do desejo primordial, marcando a impossibilidade de realização desse desejo. 
Trata-se dos efeitos da simbolização que a criança efetiva frente à sua posição em função do desejo do Outro.

A criança, por ser um ser que já nasce imerso na linguagem, realiza uma simbolização primordial de sua relação com a mãe. Freud vislumbrou esse processo em uma criança e o chamou de Fort-da, isto é, a criança simboliza a presença e ausência da mãe, reproduzindo-a em um jogo.

Após o momento do Fort-da, o significante do desejo materno é recalcado e a significação fálica produzida após a intervenção do Nome-do-Pai. A significação fálica que Lacan (1957-1958/1999) teoriza responde aos equívocos de se considerar a ameaça de castração como situada na perda do pênis, na medida em que ela permite situar o falo como uma sede de gozo privilegiado, que, no entanto, encontra-se proibido. Segundo Miller (2011), é por esse motivo que Freud localizou a castração nesse nível.

Lacan (1957-1958/1999), ao discorrer sobre os três tempos do Édipo, situa três instantes da instauração da metáfora paterna. No primeiro instante, a criança está submetida à lei materna, aos seus caprichos, processo que implica a produção de angústia. Nele, a presença do pai se dá de forma velada. No segundo tempo, o pai entra efetivamente no ternário mãe-criança-falo, e se mostra como um pai terrível e rival. No terceiro tempo, o Nome-do-Pai se mostra como um significante que liberta a criança do real da relação com a mãe, produzindo a significação fálica. Aí, o pai é menos privador e mais doador, por possibilitar à criança escolher outros objetos em sua via desejante. As implicações da inscrição do Nome-do-Pai através da metáfora paterna produzem os efeitos que Freud havia demonstrado, ou seja, a inserção do sujeito na cultura e o surgimento de um sujeito desejante.

Portanto, no seminário As formações do inconsciente, Lacan (1957-1958/1999) apresenta a sua leitura do Édipo freudiano e, ao mesmo tempo, resgata a sua essência, ou seja, a sua lógica significante. Assim sendo, Lacan dirige a sua proposta para uma teorização além do Édipo e além da proposta freudiana no que concerne o pai.

\section{O OBJETO A E O NOME-DO-PAI}

No seminário A angústia, Lacan (1962-1963/2005) realiza outra construção teórica que propicia o passo decisivo em relação à função paterna. Esse passo diz respeito à teorização sobre o objeto a como causa de desejo, uma modificação teórica que promoverá a necessidade de se reajustar a proposta lacaniana sobre a metáfora paterna.

Para Miller (1998), a teoria acerca do Nome-do-Pai pode ser pensada sob duas óticas. A primeira relaciona-se à substituição do desejo da mãe pelo Nome-do-Pai. 
Nela, o Nome-do-Pai consegue suplantar o Real e aplacar o gozo, sendo, portanto, uma metáfora eficaz. Já a segunda se refere a uma metáfora “impronunciável”, uma vez que ela está definida por uma extração de gozo que tende a não ser plenamente eficaz. Diante da atividade simbólica, há sempre um produto, um resto. Por conseguinte, o Simbólico não consegue suplantar plenamente o Real. O significante Nome-do-Pai não é um elemento que possa suprimir completamente o gozo, afinal, ele não pode ser totalmente negativizado (MILLER, 2011).

De acordo com a experiência psicanalítica, o sujeito não está presente desde o início, mas deve ser engendrado. O que pré-existe ao sujeito é o Outro, o Simbólico, e é desse lugar que o sujeito deve advir. Desde o princípio, o indivíduo nascente é forçado a se manifestar pela via da linguagem. Esse artifício é assinalado por uma perda, ou seja, ao se confrontar com o Outro e com o significante, algo escapa desse processo; trata-se do objeto a. Lacan (1962-1963/2005) afirma que, desse procedimento, é extraído o objeto a, a parte não assimilável pelo simbólico. Como resultante, surge também o sujeito barrado, aquele que deverá peregrinar de significante em significante na busca por representação, encontrando-a somente de modo parcial.

Havendo uma falta estrutural pela insuficiência simbólica em recobrir o Real, o sujeito será sempre impelido na tentativa de encontrar um suposto objeto pleno para a pulsão. Temos aí o início da atividade desejante, que se estabelece devido à falta estrutural. Logo, o objeto a é anterior ao desejo, ele está no lugar de causa.

Assim sendo, o objeto a assinala a suposição de um gozo primitivo ligado ao ser, mas que é perdido através da inscrição significante. A partir daí, o gozo está barrado para o sujeito, que o reencontra apenas por seus sucessivos retornos por meio do objeto a. Portanto, o objeto a assinala a perda e a recuperação de uma parcela de gozo.

As implicações dessa proposta são diversas para a teoria psicanalítica. Elas incidem desde a forma de se pensar as relações de objeto, pois aqui o objeto é colocado no lugar de causa, até no modo de se pensar a clínica. Mas o nosso interesse perpassa pelo questionamento que o objeto a promove ao Nome-do-Pai.

Lacan (1962-1963/2005) afirma que o mito de Totem e tabu comporta algo fundamental: a suposição de um gozo primordial do pai que, ao ser perdido, dá origem ao sujeito. Entretanto, o objeto a assinala que o assassinato do pai foi em vão, pois há uma recuperação de gozo.

O Nome-do-Pai, o pai morto, não pode suplantar todo o gozo e, por isso, a metáfora paterna se mostra insuficiente. Na última lição do seminário A angústia, Lacan (1962-1963/2005) nomeia, talvez pela primeira vez, os nomes do pai, no plural. É devido à presença do objeto a na dinâmica subjetiva que Lacan pluraliza o Nome-do-Pai. Para Lacan, o que existem são nomes que podem objetivar cumprir essa função, mas sempre de maneira parcial. 
Sendo assim, um nome-do-pai tem a incumbência de tentar simbolizar o Real, mas deixando sempre um resto. Ao mesmo tempo, Lacan (1962-1963/2005) questiona a unicidade do Outro, pois também há uma falta na própria estrutura simbólica. Diante da ausência de garantia de unicidade, um nome-do-pai tenta recobrir a falta, tenta velar a falta do Outro.

Não obstante, não é o pai que efetua a cisão fundamental que produz a queda do objeto a; quem opera esta fratura é a inserção do sujeito na linguagem. Talvez este seja o ponto chave para Lacan: após pluralizar o Nome-do-Pai, destituí-lo de sua principal prerrogativa, que é gerir a castração.

\section{A DES-EDIPIANIZAÇÃO DA CASTRAÇÃO}

Segundo Miller (2010), a castração começa a ser generalizada no momento em que Lacan (1962-1963/2005) afirma, no seminário A angústia, que o significante efetua a impossibilidade de se ter acesso ao gozo originário. Nesse sentido, Lacan demonstra que a operação de castração diz respeito à disjunção entre o gozo e o desejo efetivada pela entrada do significante no ser. Mas, nesse momento em que o indivíduo é marcado pelo significante, o sujeito ainda não existia; na verdade, ele só tem existência a partir da extração do objeto a. Sendo assim, o momento inaugural da disjunção entre o desejo e o gozo é anterior ao sujeito, e, por isso, não é possível de ser subjetivado (SOLER, 2012).

O Édipo é um evento ulterior que reedita a impossibilidade do gozo, criando um enredo para contar a história da sua perda de gozo. Segundo Lacan (1993), é necessário para o sujeito dar uma forma épica à perda de gozo. Assim, Lacan inicia a des-edipianização (generalização) da castração ao efetuar a progressiva separação do complexo de Édipo da castração.

Concomitantemente, vemos surgir o questionamento da função paterna. Em primeiro lugar, pelo fato de que não é o pai quem promove a castração ao interditar a mãe como objeto primordial do desejo, pois o desejo é anterior ao complexo de Édipo. Se, em Freud, é possível visualizar que o sujeito do desejo surge mediante a castração paterna, em Lacan pode-se entender que o sujeito e o desejo são anteriores ao Édipo e, portanto, ao pai. A mãe como objeto interdito é uma ficção que dá um formato épico à perda de gozo.

Logo, o objeto da interdição, que aparece nas fantasias do neurótico, não é o objeto da castração, pois este último está perdido desde sempre pela presença do significante. O objeto da interdição do neurótico é uma ficção. Pode-se pensar, por exemplo, a mãe como objeto da interdição paterna — o que é distinto do objeto causa de desejo. O pai não cria o desejo ao interditar a mãe como o primeiro objeto do filho. Ele não pode criar o desejo porque a causa do desejo é anterior ao pai. O que causa o desejo é a linguagem, enquanto o objeto do 
interdito paterno está implicado na estrutura da fantasia, ou seja, diz respeito à recuperação de gozo.

Afirmar que o pai é castrado é o mesmo que dizer que ele falta, por conseguinte, no momento da criação, da gênese do sujeito; o pai não estava lá. O que há é a suposição de um pai como criador. Lacan faz essa análise revendo a estrutura de Totem e tabu, já que este mito coloca o que há de importante na gênese humana - a suposição de um gozo primordial ligado ao pai e do seu assassinato.

No Seminário interrompido, Lacan (1963/2005) destaca que a suposição do gozo puro do pai é o elemento central na constituição subjetiva, uma vez que este gozo está impedido pela razão que expusemos, a saber, a incidência da linguagem. O mito do pai primevo traduz esta estruturação, ou seja, o pai morto assinala a entrada do significante no ser e, ao mesmo tempo, a suposição de um gozo originário. Não significa, porém, que havia um pai concreto que fora assassinado pelos filhos, mas que há uma suposição de um gozo primordial que se torna inacessível.

Em segundo lugar, fica notório que o Nome-do-Pai não recobre plenamente o real e o gozo. A perda de gozo deixa um resto que comporta em si mesmo um retorno de gozo. Não existe o Nome-do-Pai no singular que possa exercer esta função, antes temos nomes que objetivam fazê-lo. O Nome-do-Pai, como lugar da lei e garantia da unicidade do Outro, oculta, na verdade, a falta correspondente a ele (o Outro). No seminário As formações do inconsciente, Lacan (1957-1958/1999) havia afirmado que o Nome-do-Pai duplica o lugar do Outro, fazendo-se fiador de sua falta. O resultado, portanto, pode ser pensado em termos de certa completude.

Lacan (1962-1963/2005), ao teorizar sobre o objeto a, percebe que existe um resto da experiência do sujeito com o Outro, e que há uma falta estrutural que não pode ser preenchida pelo simbólico, ou seja, o Outro não detém todos os significantes, na medida em que falta o significante relativo ao gozo.

O gozo não pode se inscrever no significante e não há nenhum recurso simbólico que possa nomeá-lo. Essa perda estrutural se dá pela entrada do sujeito no mundo da linguagem. Tudo o que há anterior à entrada do sujeito na linguagem é impensável, e é no instante lógico anterior à linguagem que se situa o gozo originário. Gozo que é interdito pela incidência da linguagem; pelo fato de falar, os seres humanos estão impedidos do acesso ao gozo originário.

Dessa forma, a castração vai além da castração do complexo, uma vez que ela passa a ser generalizada. Isso corresponde a dizer que a castração é anterior ao Édipo por estar ligada à inserção da linguagem no sujeito, promovendo uma barreira entre o desejo e o gozo. 
É nesse sentido que toda função do a refere-se apenas à lacuna central que separa, no nível sexual, o desejo do lugar do gozo, e nos condena ao imperativo que faz com que, para nós, o gozo, por natureza, não esteja prometido ao desejo. (LACAN, 1962-1963/2005)

Entretanto, a incidência do sujeito na linguagem deixa um resto, pois o gozo é impossível de se negativar. O objeto do qual se trata, o objeto a, é o resto da operação da linguagem que instaura o desejo. De maneira análoga à impossibilidade de negativização do gozo, a falta também é impossível de se suprimir, a não ser pela presença do próprio objeto a. É isso que a angústia assinala; o instante de interseção entre o gozo e o desejo, a presença do objeto onde deveria surgir a falta. Diferentemente do mito edípico que asseverava o pai como castrador e promotor do desejo, Lacan retifica a posição paterna, que não é castrar, tampouco instaurar o desejo, pois estas operações são anteriores ao pai.

O desejo é instaurado pela linguagem e pela queda primitiva do objeto a e, nesse sentido, não é mais possível pensar um pai universal que efetive as funções que o mito freudiano demonstra. O que existem são nomes que promovem não a castração, mas a ligação do desejo à lei. Em outros termos, a função do pai é uma função suplementar à da linguagem. Além de promover a ligação entre desejo e lei, o pai também funciona como véu, isto é, ele visa ocultar a incompletude do Outro.

Miller (2011) afirma que a perda de gozo diz respeito a uma fratura no interior do sujeito, sendo caracterizada como algo ao mesmo tempo exterior a ele, mas também muito íntimo: trata-se do êxtimo, neologismo criado por Lacan. Ao mesmo tempo, diz respeito à perda de gozo que o simbólico propicia e concomitantemente dá um lugar para o sujeito no Outro.

Contudo, por que o Outro aparece nas fantasias neuróticas como castrador? Lacan (1962-1963/2005) fala de um desejo de castração, isto é, o sujeito deseja se desvencilhar do gozo do Outro que lhe é nefasto; ele objetiva se separar dele, uma vez que o que é demandado pelo Outro é justamente o objeto a. Não saber qual objeto a o sujeito representa para o Outro determina uma das modalidades de angústia.

Miller (2011) afirma que o neurótico não quer sacrificar sua castração ao Outro, ou seja, não está disposto a ascender ao gozo do Outro, e, para lograr êxito em seu objetivo, ele se esforça a dar uma forma épica à estrutura lógica de sua entrada no mundo da linguagem. Assim sendo, ele erige um Outro castrador do qual ele deve fugir diante de sua presença. 


\section{O PAI: UMA FUNÇÃO SUPLEMENTAR}

Em nosso cenário civilizatório, é comum questionarmos a função paterna. Uma vez que Lacan a interroga e altera os seus preceitos, é lícito interrogarmos sobre o que resta a ela, já que a operação de castração não se relaciona com a sua atuação. O que resta ao pai, se ele não é o agente da castração?

No seminário A angústia, Lacan (1962-1963/2005) discorre sobre os nomes do pai no plural e também afirma que a extração do objeto a cria um desejo metonímico por excelência, ou seja, aquele que irá deslizar sempre, de objeto em objeto, nunca encontrando uma satisfação plena.

Mas ele também discorre acerca de um objeto passado para o campo da história do sujeito, historizado. A passagem de um desejo infinito para um desejo finito e presente no campo da história é a função suplementar do pai.

Dito de outra maneira, o pai é a condição de aparecimento de um desejo enquanto finito. Em termos freudianos, dir-se-ia fixado. Fixado, certamente, por um objeto a, mas um objeto a passado no campo da história, que é historizado, que tem, portanto, índices imaginários e significantes, ao mesmo tempo. Vê-se, imediatamente, por que o desejo do pai é a lei. (SOLER, 2012, p. 163)

O pai Ideal, o pai morto, é inalcançável, fazendo frente ao desejo do sujeito. Nesse sentido, o pai Ideal não tem serventia para o sujeito por não poder servir-se dele. Mais adiante em seu ensino, Lacan (1975-1976/2007) afirma que o sujeito deve prescindir do pai com a condição de servir-se dele. O pai do qual o sujeito pode se servir é o pai da perversion. Essa é a razão de Lacan nos dizer algo a respeito da perversão, nessa última lição do seminário $A$ angústia.

A perversão é uma condição que fixa o desejo em um ponto específico. Freud (1905/1996) afirmou que a fixação do desejo é uma condição presente na dinâmica pulsional. A pulsão se satisfaz com qualquer objeto, mas, uma vez eleito na fantasia um objeto de satisfação e desejo, ele será invariável.

Para Lacan (1962-1963/2005), os nomes do pai têm essa função de fixar o desejo. Pode-se pensar que o pai, ao proibir à mãe como objeto de desejo, está fixando-o em um objeto bastante preciso. Depreende-se que é a função paterna que efetua a ligação entre o desejo e a lei, pois, ao proibir, o pai aponta um caminho para o desejo. Evidentemente que, por se tratar de uma função, $f(x)$, qualquer nome pode entrar no lugar da variável da função. Por esse motivo, essa nova leitura é profícua para analisar as mais diversas formações familiares de nosso tempo. A formação edípica é apenas um modo de se estruturar essa função e, portanto, não o único. Por conseguinte, deve-se buscar sempre o que serviu como nome do pai para o sujeito, conforme nos diz Miller (1997). 
De todo modo, o caminho apontado por um nome do pai está relacionado ao objeto fixado de sua história. Como exemplo, Lacan argumenta que uma mulher pode ser colocada no lugar de causa de desejo, ou seja, objeto fixado do pai, que é transmitido ao filho. Entretanto, muitos objetos podem ocupar esse lugar. Em suma, trata-se de uma interrogação acerca do objeto a. Essa assertiva diz respeito à saída singular de um pai que tentou responder aos impasses do desejo, que pode ocorrer por meio de uma mulher-causa.

Ainda permanece uma questão que não podemos deixar de considerar: qual seria o papel da mãe nesse novo cenário de pluralização do Nome-do-Pai? Desde Os complexos familiares, Lacan (1938/2003) atribui à mãe uma função simbólica. Desnaturalizando a família humana, ao inscrevê-la no campo da cultura e ao substituir os laços consanguíneos pelos laços simbólicos, Lacan transforma as figuras do pai e da mãe em funções: função de nomeação e função de cuidado, respectivamente. Estas funções são retomadas em Nota sobre a criança, onde Lacan (1969/2003) afirma a necessidade da transmissão de um desejo para a constituição do sujeito, um desejo não anônimo.

A implicação da subjetividade materna na sua relação com a criança é aqui colocada em evidência. Podemos destacar ainda, em O seminário, livro 22: R. S. I., outro esclarecimento acerca das funções parentais. Do lado do pai, o que importa não é somente sua relação com a lei, mas também com o gozo. O amor e o respeito aos quais um pai tem direito são tributários da sua relação com a mãe, enquanto mulher objeto do seu desejo e versão do seu gozo.

Marie-Hélène Brousse (2005) demonstra que o termo "parentalidade" é a manifestação dos efeitos das transformações da civilização sobre a ordem familiar. Nele, temos uma simetria entre o pai e a mãe no que concerne à ordem familiar. À época da pluralização dos nomes do pai, pai e mãe estão conectados à criança e verificamos um crescente apagamento da diferença entre as funções do pai e da mãe, o que coloca impasses para o exercício da função materna. Os laços familiares tendem a ser mais orientados pelo objeto a e pelos modos de gozo implicados nas parcerias, do que pelas identificações e ideais. O mesmo pode ser dito do exercício da função paterna: o pai podendo ser substituído por seus pares.

\section{CONCLUSÃO}

Podemos perceber que o mito desvelou para Freud a maneira de estruturação do sujeito e de sua relação com o desejo e o gozo. Cabe ressaltar que Freud se vale do mito para construir sua proposta e que essa assertiva não responde aos preceitos ideológicos ou sociais. Se Freud encontrou problemas terminológicos ao criar sua proposta pulsional, verificamos algo parecido com a função paterna. Por se tratar 
de uma função, $f(x)$, qualquer nome pode entrar nesse lugar. Chamar a função paterna de função terceira, ou qualquer outro nome, não altera suas nuances e apenas teria sentido para responder a alguns anseios ideológicos e sociais. No entanto, a própria construção do mito oculta a estrutura lógica da entrada do sujeito no mundo da linguagem. Lacan desvela a lógica do processo de estruturação do sujeito e descobre um resto impossível de se simbolizar, o objeto a.

A elaboração do objeto a demonstra a insuficiência do Nome-do-Pai e assinala que a castração é uma operação pré-subjetiva e anterior ao complexo de Édipo, deixando de ser conotada como uma prerrogativa paterna. O fato de o neurótico vislumbrar um pai castrador significa que o pai como agente da castração está presente na fantasia. Cada sujeito constrói para si um mito individual para dar forma à suposição da perda de gozo, pois a castração corresponde a esse processo de perda ao qual o sujeito ascende ao se confrontar com a linguagem.

O pai universal que ditava a lei e interditava o filho é deslocado para outro lugar. Lacan inicialmente lhe dá atributos lógicos como um elemento primordial de simbolização, mas depois reconhece que esse elemento não é universal; antes, é uma variável em uma função, isto é, pode ser ocupado por qualquer outro elemento. Portanto, resta sempre saber o que serviu como pai para cada sujeito em sua história.

Lacan não retroage à ideia de um pai concreto. Antes, ele passa a privilegiar com mais vigor o registro da "singularidade" em detrimento da categoria lógica “universal”. O pai é um significante, um nome, um operador que apenas pode ser analisado na singularidade de cada sujeito. Em suma, ao pluralizar o nome do pai, Lacan insere um questionamento sobre o desejo e o gozo presentes na estruturação subjetiva de cada sujeito.

Recebido em: 30 de outubro de 2015. Aprovado em: 29 de outubro de 2016.

\section{REFERÊNCIAS}

BROUSSE, M. H. Un néologisme d'actualité: la parentalité. La cause freudienne, n. 60, Paris: Navarin, 2005. P. 117-123.

FREUD, S. A dissolução do complexo de Édipo (1924). Rio de Janeiro: Imago, 1996. (Ed. standard brasileira das obras completas, 19).

A distorção nos sonhos (1900). Rio de Janeiro: Imago, 1996. (Ed. standard brasileira das obras completas, 4).

Organização genital infantil (1923). Rio de Janeiro: Imago, 1996.

(Ed. standard brasileira das obras completas, 19). 
Totem e tabu (1913). Rio de Janeiro: Imago, 1996. (Ed. standard brasileira das obras completas, 13).

Três ensaios sobre a sexualidade (1905). Rio de Janeiro: Imago, 1996. (Ed. standard brasileira das obras completas, 7).

LACAN, J. A angústia (1962-1963). Rio de Janeiro: J. Zahar, 2005. (O seminário, 10). . A excomunhão (1964). In: Os quatro conceitos fundamentais da psicanálise. Rio de Janeiro: J. Zahar, 1988. (O seminário, 11). Agalma (1961-1962). In: .A transferência. Rio de Janeiro:

J. Zahar, 1992. (O seminário, 8).

A identificação (1961-1962). Recife: Centro de Estudos Freudianos de Recife, 2003. (O seminário, 9). As formações do inconsciente (1957-1958). Rio de Janeiro: J. Zahar, 1999. (O seminário, 5).

Da criação ex-nihilo (1959-1960). In: A ética da psicanálise.

Rio de Janeiro: J. Zahar, 2008. (O seminário, 7). Do uso lógico do sinthoma ou Freud com Joyce (1975-1976). In:_ O sinthoma. Rio de Janeiro: J. Zahar, 2007. (O seminário, 23). Édipo e Moisés e o Pai da horda (1969-1970). In:

O avesso da psicanálise. Rio de Janeiro: J. Zahar, 1992. (O seminário, 17). . Nota sobre a criança (1938b). In: Outros escritos. Rio de Janeiro: J. Zahar, 2003. . O mito individual do neurótico (1953). Rio de Janeiro: J. Zahar, 2008. . Os complexos familiares na formação do indivíduo (1938a). In: Outros escritos. Rio de Janeiro: J. Zahar, 2003.

Os nomes do pai (1963). In: Nomes-do-Pai. Rio de Janeiro: J. Zahar, 2005.

R. S. I. (1974-1975). Inédito. (O seminário, 22).

Seminário do homem dos lobos (1952). Inédito. Disponível em: <http://pt.scribd.com/doc/64010301/seminario-sobre-o-homem-dos-lobos>. Acesso em: 02 set 2013.

Subversão do sujeito e a dialética do desejo (1960). In:

Escritos. Rio de Janeiro: J. Zahar, 1998. Televisão. Rio de Janeiro: J. Zahar, 1993.

MARCOS, C. M. As versões freudianas do pai. Psicologia em Revista. Belo Horizonte, 2003. V. 10, n. 14.

MILLER, J.-A. Comentario del seminário inexistente. In: Conferencias porteñas: tomo II desde Lacan. Buenos Aires: Paidós, 2010.

Extimidad. Buenos Aires: Paidós, 2011.

. La angustia: introduccion al Seminario X de Jacques Lacan. Buenos

Aires: Del Nuevo Extremo, Espana: RBA, 2007.

O segredo do Nome-do-Pai. In: Lacan elucidado: palestras no Brasil.

Rio de Janeiro: J. Zahar, 1997.

Preâmbulo. In: Os Nomes-do-Pai. Rio de Janeiro: J. Zahar, 2005.

Psicoanálisis y psicoanálisis. In: Los signos del goce. Barcelona:

Paidós, 1998. 
Uma reflexão sobre o Édipo e seu mais além. In: Orientação Lacaniana — Boletim da Escola Brasileira de Psicanálise. Dez 2013. Disponível em: <http://www.ebp.org.br/dr/orientacao/orientacao006.asp>. Acesso em: 09 de setembro de 2015.

SOLER, C. Seminário de leitura do texto ano 2006-2007: Seminário A angústia, de Jacques Lacan. São Paulo: Escuta, 2012.

Eduardo Augusto de Souza Sales

eduardosales.psicologia@gmail.com

Cristina Moreira Marcos

cristinammarcos@gmail.com 